\title{
Highly Efficient Ir-Catalyst for the Solventless Dehydrogenation of Formic Acid: The Key Role of an $\mathbf{N}$-heterocyclic Olefin
}

\author{
Amaia Iturmendi, ${ }^{[a]}$ Manuel Iglesias ${ }^{*},{ }^{[a]}$ Julen Munarriz, ${ }^{[b]}$ Victor Polo, ${ }^{[b]}$ Vincenzo Passarelli, ${ }^{[c]}$ Jesús J. \\ Pérez-Torrente, ${ }^{[a]}$ Luis A. Oro*[a]
}

\begin{abstract}
The use of formic acid as a hydrogen energy carrier has sparked the interest of the scientific community in the development of catalysts that promote its selective dehydrogenation. Most of the catalysts so far reported require the use of solvents that reduce the hydrogen density of the mixture and may even damage the fuel cell electrode materials. We present here a sturdy iridium catalyst that features a PCP ligand based on an $\mathrm{N}$-heterocyclic olefin $(\mathrm{NHO})$ scaffold, which is remarkably active for the dehydrogenation of neat formic acid. Related complexes that present bis-phosphine ligands without an $\mathrm{NHO}$ donor moiety give rise to noticeably lower activities. This highlights the importance of the role played by the $\mathrm{NHO}$ in the activity of the catalyst. Moreover, by reacting the $\operatorname{IrPCP}(\mathrm{NHO})$ catalyst with an excess of $\mathrm{HCOOH}$ and pyridine we were able to isolate a plausible reaction intermediate. These postulations have been substantiated by DFT calculations.
\end{abstract}

The growth of global energy presents urgent challenges associated with the sustainability and environmental impact of fossil fuels. ${ }^{[1]}$ The energy stored in the chemical bonds of $\mathrm{H}_{2}$ molecules may be released by electrochemical combustion in fuel cells affording water as the only reaction product. This alternative technology would permit the exploitation of sustainable energy sources such as biomass or water, ${ }^{[2]}$ and the storage of the excess electrical power that renewable energy sources generate off-peak by water electrolysis. ${ }^{[3]}$ The use of hydrogen gas as a sustainable energy vector, however, presents several drawbacks, mainly related to its storage and transportation. The use of liquid organic hydrogen carriers (LOHCs) has been proposed as a viable alternative to bypass the issues that liquefaction or highpressure storage of $\mathrm{H}_{2}$ present. ${ }^{[4]}$ In this regard, formic acid (FA) shows several advantages compared to other LOHCs: (i) $\mathrm{CO}_{2}$ may be hydrogenated to FA to render a carbon-neutral cycle of hydrogen storage; (ii) fuel-cell-grade hydrogen requires levels of CO below 10 ppm, which are achievable by FA dehydrogenation; (iii) the energy density of FA is higher than that of most LOHCs and $\mathrm{H}_{2}$; (iv) FA presents less toxicity hazards compared to other hydrogen carriers such as ammonia, amine boranes or

[a] A. Iturmendi, Dr. M. Iglesias, Prof. J. J. Pérez-Torrente, Prof. L. A. Oro

Departamento Química Inorgánica - Instituto Síntesis Química y Catálisis Homogénea (ISQCH)

Universidad de Zaragoza - CSIC

C/Pedro Cerbuna 12, 50009 Zaragoza, Spain

E-mail:miglesia@unizar.es, oro@unizar.es

[b] J. Munárriz, V. Polo

Departamento Química Física - Instituto de Biocomputación y

Física de Sistemas Complejos (BIFI)

Universidad de Zaragoza

Pedro Cerbuna 12, 50009 Zaragoza, Spain.

[c] V. Passarelli

Centro Universitario de la Defensa

Ctra. Huesca s/n, ES-50090 Zaragoza, Spain. methanol. ${ }^{[5]}$ The ratio between the amount of $\mathrm{H}_{2}$ released and the volume of the reaction mixture used in FA dehydrogenation is crucial to the implementation of FA as a hydrogen carrier. The solventless dehydrogenation of FA reduces drastically the volume of the reaction mixture compared to processes that require a solvent, which result in a higher energy density. Moreover, the presence of volatile organic solvents may damage the fuel cell electrode materials. Many outstanding catalysts for FA dehydrogenation have been described since the seminal work by Beller ${ }^{[6]}$ and Laurenczy, ${ }^{[7]}$ the best results being usually obtained in solution. ${ }^{[8]}$ However, examples of homogeneous catalyst that operate efficiently in neat $\mathrm{HCOOH}$ are scarce. ${ }^{[9]}$ The iridium complex recently reported by Williams and co-workers, namely $\left[\operatorname{Ir}(\mathrm{COD})\left({ }^{t} \mathrm{Bu}_{2} \mathrm{PCH}_{2}(2-\mathrm{py})\right)\right] \mathrm{CF}_{3} \mathrm{SO}_{3}$ is the most efficient hitherto reported for the solventless dehydrogenation of FA. Namely, a TOF value of $13320 \mathrm{~h}^{-1}\left(3.7 \mathrm{~s}^{-1}\right)$ and a TON of 12530 after $13 \mathrm{~h}$ were reported for this catalyst. ${ }^{[10]}$

Herein we describe a proficient Ir-catalyst for the solventless dehydrogenation of FA, which features a PCP ligand based on an $\mathrm{NHO}$ scaffold $(\mathrm{NHO}=\mathrm{N}$-heterocyclic olefin). The catalyst $\left[\operatorname{lr}(\mathrm{PCP})(\mathrm{COD}) \mathrm{BF}_{4},{ }^{[11]} \quad(\mathrm{PCP} \quad=\quad 1,3-\mathrm{bis}(2-\right.$ (diphenylphosphanyl)ethyl)-2-methyleneimidazoline and $\operatorname{cod}=$ 1,5-cyclooctadiene) brings about outstanding activities in neat FA, which can be improved in the presence of water.

Initial catalytic tests aimed at exploring the activity of Ir-NHO complexes (1 and $\mathbf{2})^{[10 a]}$ in the dehydrogenation of neat FA (Figure 1). Under unoptimized reaction conditions, $0.016 \mathrm{~mol} \%$ of the precatalyst and $5 \mathrm{~mol} \%$ of $\mathrm{HCOONa}$ at $80{ }^{\circ} \mathrm{C}, 1$ proved to be the most active pre-catalyst. NHO-Ir(III) complex 2 performed significantly worse than $\mathbf{1}$, probably due to the fact that one of the coordination positions is blocked by a strongly coordinating carbonyl ligand. $\operatorname{Ir}(\mathrm{I})$ complexes related to $\mathbf{1}$, namely $\mathbf{3}$ and $\mathbf{4},{ }^{[12]}$ which present a chelating bis-phosphine without an NHO moiety, are noticeably less active than its $\mathrm{NHO}$-containing counterpart.
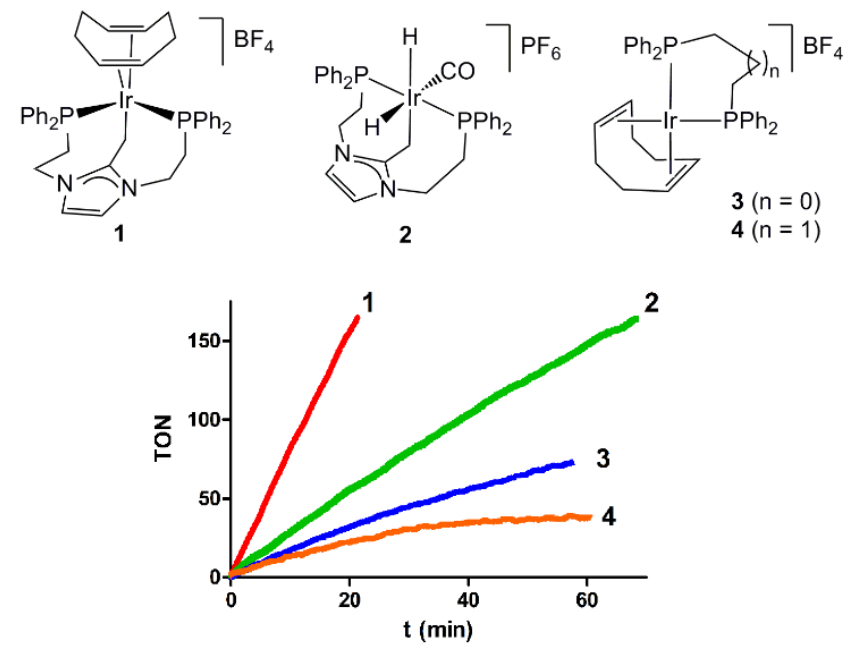
Figure 1. Depiction of pre-catalysts 1-4 and reaction profiles for the dehydrogenation of neat FA $(0.016 \mathrm{~mol} \%$ of Ir-catalyst, $5 \mathrm{~mol} \%$ of HCOONa at $80 \stackrel{\circ}{\circ})$.

In order to shed light on the nature of the active species, $\mathbf{1}$ was dissolved in $\mathrm{CH}_{2} \mathrm{Cl}_{2}$ and heated to $50{ }^{\circ} \mathrm{C}$ in the presence of 4 equivalents of $\mathrm{HCOOH}$. Interestingly, the reaction does not proceed under strictly anhydrous conditions. The addition of traces of $\mathrm{H}_{2} \mathrm{O}\left(30 \mathrm{ppm}\right.$ of $\left.\mathrm{H}_{2} \mathrm{O}\right)$ triggered the formation of a new dihydride species that decomposes upon isolation. Addition of a large excess of pyridine (ca. 20 eq.) to the reaction mixture allows the preparation of the new dihydride complex $\left[\operatorname{lr}(\mathrm{H})_{2}(\mathrm{PCP})(\mathrm{py})\right]_{B F_{4}}(\mathbf{5})$ (Scheme 1), which appears always together with small amounts of an unidentified hydride species. When the reaction was performed in $\mathrm{CH}_{3} \mathrm{CN}$, in the presence of $\mathrm{HCOONa}$ at $80^{\circ} \mathrm{C}$, the clean formation of the dihydride complex 6 was observed. However, the product decomposed upon purification (SI). Addition of excess 3,5-dimethylpyridine (3,5$\mathrm{Me}_{2} \mathrm{py}$ ) to a solution of 5 resulted in the formation of the related complex 6 (Scheme 1), which illustrates the facile access to this coordination site.

Crystals of complex 5 and $\mathbf{6}$ were obtained by slow diffusion of pentane into a saturated dichloromethane solution of the crude mixture. The molecular structures of cations 5 and $\mathbf{6}$ (Scheme 1) show a slightly distorted octahedral geometry around the iridium center, in which the PCP ligand occupies three meridional coordination sites, showing a P1-Ir-P2 angle of $166.87(12)^{\circ}$ and 166.67(6), respectively. The other three coordination sites are occupied by two hydride ligands (one trans to the pyridine ligand pointing towards the $\mathrm{NHO}$ moiety and the other trans to the ylidic carbon atom) and a py ligand in $5(\mathrm{Ir}-\mathrm{N}, 2.196(9) \AA)$ or a 3,5$\mathrm{Me}_{2}$ py in 6 (Ir-N, 2.190(5) ̊).

Diagnostic peaks in the ${ }^{1} \mathrm{H}$ NMR spectrum of $\mathbf{5}$ are the two doublets of triplets assigned to the two inequivalent hydrides, which appear at $\delta-15.30$ and $-23.64 \mathrm{ppm}$ in $\mathrm{CD}_{2} \mathrm{Cl}_{2}\left({ }^{2} \mathrm{~J}_{\mathrm{H}-\mathrm{P}}=15.3\right.$ and $20.4 \mathrm{~Hz}$, respectively; ${ }^{2} \mathrm{~J}_{\mathrm{H}-\mathrm{H}}=6.2 \mathrm{~Hz}$ ). The ${ }^{31} \mathrm{P}\left\{{ }^{1} \mathrm{H}\right\} \mathrm{NMR}$ in $\mathrm{CD}_{2} \mathrm{Cl}_{2}$ shows a siglet at $\delta-7.3 \mathrm{ppm}$ that can be assigned to the two equivalent phosphorus atoms of the PCP ligand.

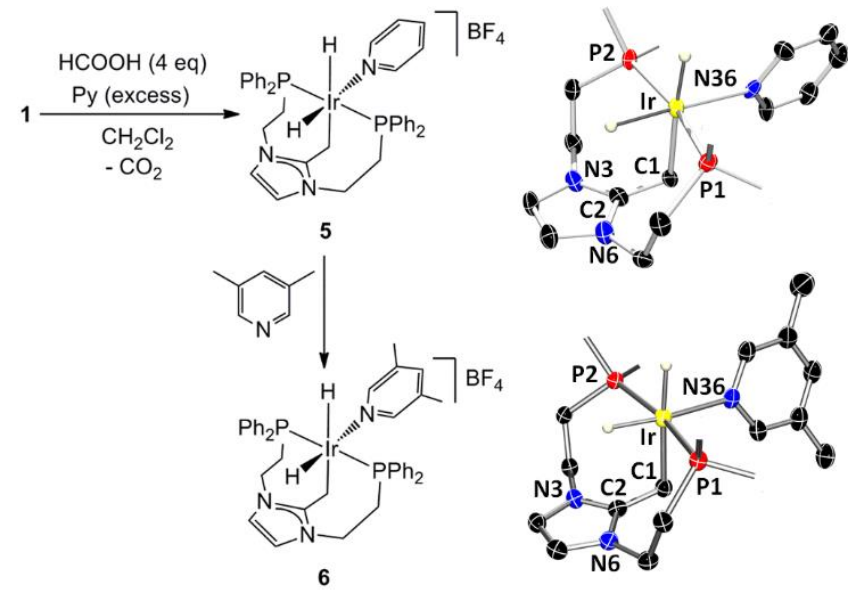

Scheme 1. Synthesis and ORTEP view of 5 and $\mathbf{6}$ (ellipsoids are drawn at $50 \%$ probability level). The phenyl rings and $\mathrm{PF}_{6}{ }^{-}$counterions were omitted for clarity. Selected bond lengths $(\AA)$ and angles $(\stackrel{\circ}{)})$ : 5: Ir-C1 2.258(12), Ir-P1 2.284(3), IrP2 2.275(3), Ir-N36 2.196(9), C1-C2 1.434(16), P1-Ir-P2 166.87(12), Ir-C1C2 100.2(8). 6: Ir-C1 2.247(6), Ir-P1 2.2751(17), Ir-P2 2.2733(17), Ir-N36 2.190(5), C1-C2 1.430(9), P1-Ir-P2 166.67(6), Ir-C1-C2 100.9(4).

The reaction of $\mathbf{3}$ or $\mathbf{4}$ with 4 eq. of $\mathrm{HCOOH}$ and 20 eq. of pyridine in $\mathrm{CD}_{2} \mathrm{Cl}_{2}$ (in the presence or absence of $\mathrm{H}_{2} \mathrm{O}$ ) led to the formation of a hydride complex that immediately decomposes to give fine black particles. This suggests that, in the absence of the additional stabilization provided by the $\mathrm{NHO}$ moiety, the unsaturated species that likely results from the loss of the COD ligand aggregates to give inactive Ir-particles.

In order to explore the reaction mechanism, the catalysis was studied by NMR in DMSO-d $\mathrm{d}_{6}\left(80^{\circ} \mathrm{C}, 1 \mathrm{~mol} \%\right.$ of $1,10 \mathrm{~mol} \%$ $\mathrm{HCOONa}$ ). The ${ }^{1} \mathrm{H}$ NMR spectrum shows the formation of free $\mathrm{H}_{2}$ and two doublets of triplets $\left({ }^{2} \mathrm{~J}_{\mathrm{H}-\mathrm{P}}=17.5 \mathrm{~Hz},{ }^{2} \mathrm{~J}_{\mathrm{H}-\mathrm{H}}=5.7 \mathrm{~Hz}\right.$ ) at $\delta-$ 15.29 and $-17.38 \mathrm{ppm}$, which correspond to the only metallic species observed by NMR. Moreover, a singlet at $\delta-16.7 \mathrm{ppm}$ is observed in the ${ }^{31} \mathrm{P}$ NMR spectrum. These peaks are reminiscent of those present in the NMR spectra of complexes $\mathbf{2}$ and $\mathbf{5}$.

Theoretical calculations predict the dissociation of the 1,5cyclooctadiene ligand (COD) as a pre-activation step, thus allowing FA coordination (A to B, Figure 2). Subsequently, the intramolecular activation of the $\mathrm{O}-\mathrm{H}$ bond through TSBC leads to the monohydride-formate species $\mathbf{C}$. The formation of $\mathrm{CO}_{2}$ from the formate ligand has been often proposed to occur via $\beta$-hydride elimination ${ }^{[13,14,15]}$ or hydride abstraction. ${ }^{[14,16]}$ In this case, the $\beta$ hydride elimination pathway is more favorable due to the presence of two accessible coordination sites. The coordination of a molecule of FA to $\mathbf{C}$ yields $\mathbf{D}$, which evolves to $\mathbf{E}$ by deprotonation, thus leading to an energy barrier of $17.8 \mathrm{Kcal} / \mathrm{mol}$ for TSCF. Elimination of $\mathrm{CO}_{2}$ from $\mathbf{C}$ yields the dihydride intermediate $\mathbf{F}$, which, upon coordination of formate, affords $\mathbf{G}$ ($3.6 \mathrm{kcal} / \mathrm{mol})$. 


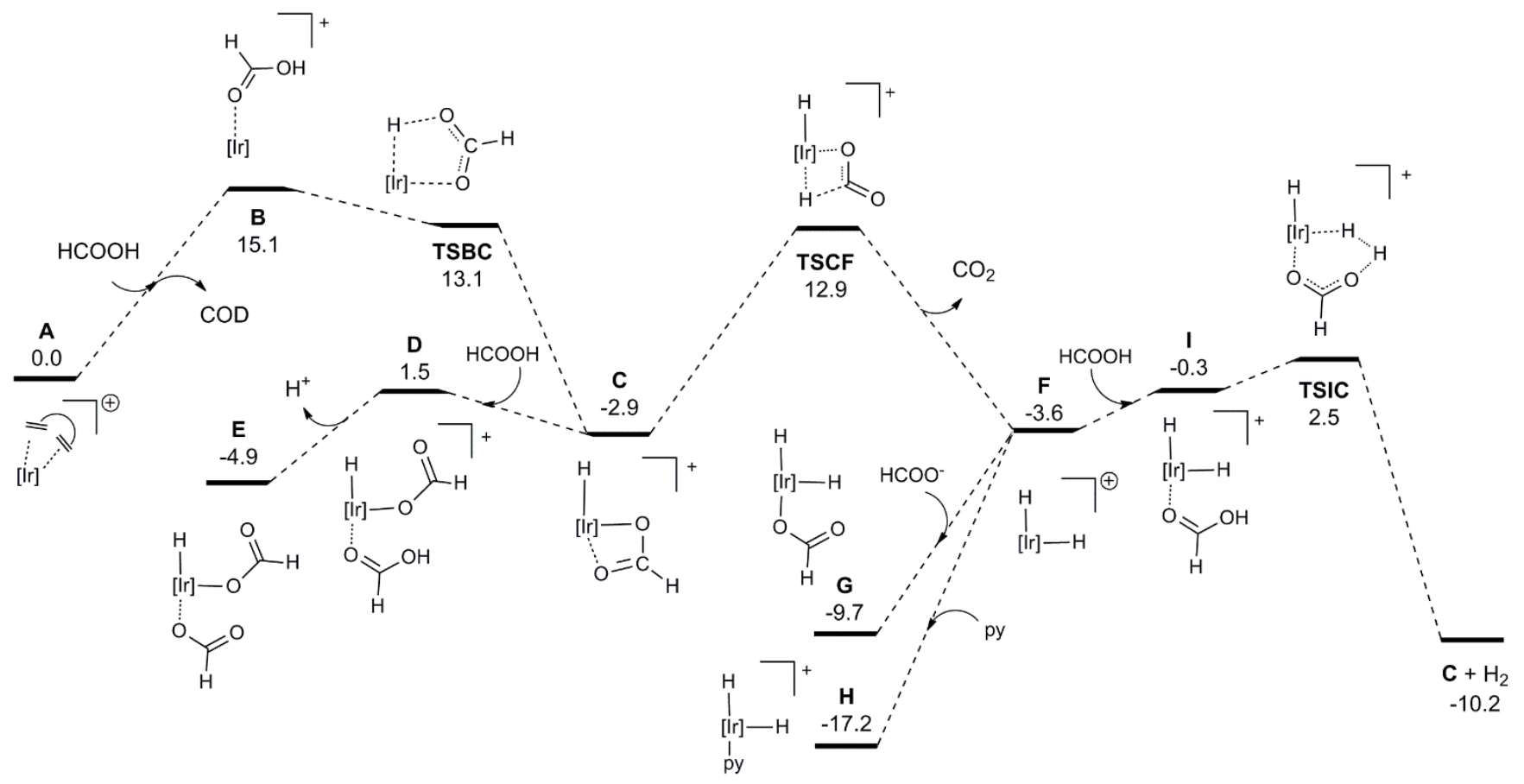

Figure 2. DFT calculated Gibbs free energy profile (in $\mathrm{kcal} \mathrm{mol}^{-1}$ ) for the dehydrogenation of FA.

This species can be stabilized by exchange of the formate ligand by pyridine to give $\mathbf{H}(-17.2 \mathrm{kcal} / \mathrm{mol})$, which agrees with the stoichiometric experiments that afford $\mathbf{5}$ and the in operando NMR experiments described above. Coordination of a molecule of $F A$ to $\mathbf{F}$ yields $\mathbf{I}$, which upon protonation of one of the hydride ligands regenerates $\mathbf{C}$ and produces a molecule of $\mathrm{H}_{2}$. The intermolecular protonation of a hydride ligand by $\mathrm{FA}$ has been suggested in the literature. ${ }^{[14,15,17]}$ However, in this case, the vacant coordination site in $\mathrm{F}$ permits the coordination of $\mathrm{FA}$ and the intramolecular protonation of the hydride by a low energy process dictated by TSIC.

It is noteworthy that the coordination mode of the PCP ligand changes upon pre-activation, from facial in $\mathbf{A}$ to meridional in $\mathbf{C}$. Throughout the catalytic cycle the PCP ligand adopts a meridional coordination in $\operatorname{Ir}(\mathrm{I})$ and $\operatorname{Ir}(\mathrm{III})$ centers. All these species feature an $\mathrm{NHO}$ moiety that coordinates end-on by the terminal $\mathrm{C}$ atom; however, the Ir-C-C bond angle is, in all cases, ca. 100 (similar angles are observed in the crystal structures of $\mathbf{5}$ and $\mathbf{6}$ ), far from the $114^{\circ}$ observed for $\mathbf{A}$ and the $109^{\circ}$ expected for an $\mathrm{sp}^{3}$ hybridization. This suggests that donation from the $\pi$ orbital of the olefin is substantial in these species (SI).

The positive effect of the addition of catalytic amounts of water in the formation of $\mathbf{5}$ prompted us to evaluate the impact of $\mathrm{H}_{2} \mathrm{O}$ concentration in the dehydrogenation of FA. To our delight, not only was the catalyst stable to water but also its activity improved. The addition of water, from $5 \mathrm{~mol} \%$ to $150 \mathrm{~mol} \%$, resulted in a progressive improvement of the activity (Figure 3). Remarkably, $\mathrm{H}_{2} \mathrm{O}$ addition increases the reaction rate until it reaches a plateau at $30 \mathrm{~mol} \%$. From $50 \mathrm{~mol} \%$ onwards a sharper rise of activity occurs. Above $100 \mathrm{~mol} \%$ no significant increase was observed upon $\mathrm{H}_{2} \mathrm{O}$ addition. Plausibly, this intricate behavior could be ascribed to the fact that, in addition to the role that $\mathrm{H}_{2} \mathrm{O}$ molecules play in the dissociation of $\mathrm{HCOOH}$, a significant percentage of the added water may engage in the solvation of $\mathrm{HCOONa}$ or be involved in hydrogen bonding with $\mathrm{HCOOH}$ molecules. Moreover, transition state stabilization through hydrogen bonding should not be discarded. ${ }^{[18]}$

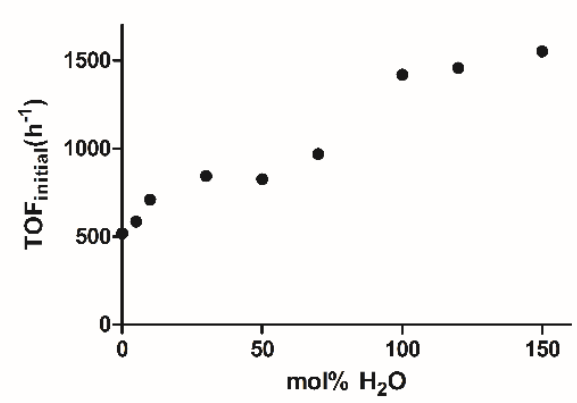

Figure 3. Effect of $\mathrm{H}_{2} \mathrm{O}$ addition on $\mathrm{FA}$ dehydrogenation rate using $5 \mathrm{~mol} \%$ of $\mathrm{HCOONa}$ and $0.016 \mathrm{~mol} \%$ of 1 .

Subsequently, due to the fact that the activity of FA dehydrogenation catalysts has been proved to depend on the $\mathrm{pH}$ of the solution, ${ }^{[15,19]}$ the effect of formate loading was also studied. Figure 4 shows the TOF values for HCOONa loadings that range from $5 \mathrm{~mol} \%$ to $100 \mathrm{~mol} \%$, with the optimum base concentration being $30 \mathrm{~mol} \%$ independently of the $\mathrm{H}_{2} \mathrm{O}$ concentration (5 mol\% or $100 \%$ of $\mathrm{H}_{2} \mathrm{O}$ ). 


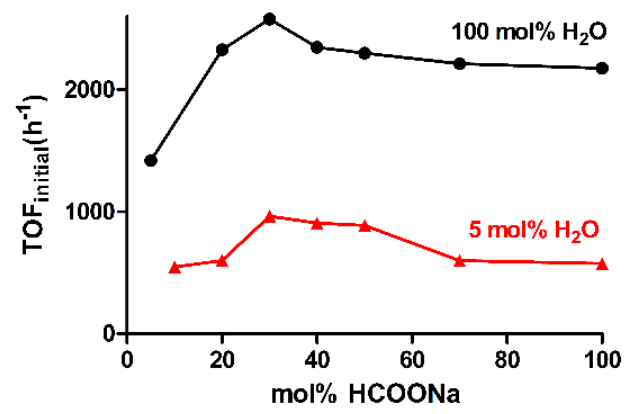

Figure 4. Effect of HCOONa addition on FA dehydrogenation rate with 100 mol\% and $5 \mathrm{~mol} \%$ of $\mathrm{H}_{2} \mathrm{O}$, using 0.016 mol\% of 1 .

The temperature was optimized using 100 mol\% of $\mathrm{H}_{2} \mathrm{O}$ and 30 mol\% of sodium formate, displaying the best performance at 90 ${ }^{\circ} \mathrm{C}$ (Figure 5). The TOF values calculated at $60,70,80$ and $90 \stackrel{\circ}{\circ}$ were respectively, 410, 1390, 2580 and $5170 \mathrm{~h}^{-1}$. The positive effect of the increasing temperature on the catalytic performance suggests that the catalyst is thermally stable in this range of temperatures. ${ }^{[20]}$ In this regard, addition of a drop of mercury to the reaction mixture shows no influence in the reaction rate, which supports the homogeneous nature of the active species.

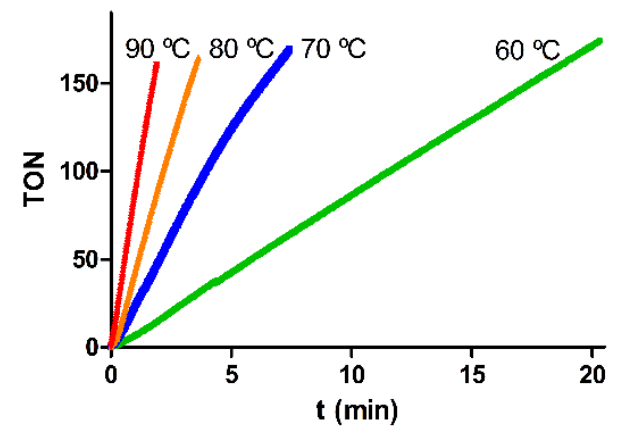

Figure 5. Reaction profiles for the dehydrogenation of $\mathrm{FA}$ in the temperature range $60-90^{\circ} \mathrm{C}\left(100 \mathrm{~mol} \%\right.$ of $\mathrm{H}_{2} \mathrm{O}, 30 \mathrm{~mol} \%$ of $\mathrm{HCOONa}$ and $0.016 \mathrm{~mol} \%$ of 1$)$.

Remarkably, a TOF value of $11590 \mathrm{~h}^{-1}$ and a TON of 8030 (after $5 \mathrm{~h}$ ) were obtained upon reduction of the catalyst (1) loading to $0.001 \mathrm{~mol} \%$. These values compare well with the highest TOF and TON values so far reported for the solventless dehydrogenation of FA. Under these conditions the formation of carbon monoxide was below the detection limit of the infrared spectrum (3 ppm). ${ }^{[3 a]}$

The reaction rates measured at temperatures between 60 and $90{ }^{\circ} \mathrm{C}$ allowed the experimental estimation of the activation energy by the Arrhenius plot $\left(E_{a}=19.9 \pm 0.8 \mathrm{Kcal} / \mathrm{mol}\right.$ at 100 mol\% of $\mathrm{H}_{2} \mathrm{O}, 30 \mathrm{~mol} \%$ of $\mathrm{HCOONa}$ and $0.016 \mathrm{~mol} \%$ of 1$)$. The activation energy in the absence of $\mathrm{H}_{2} \mathrm{O}$ was also calculated under the same experimental conditions (to give a value of $24.5 \pm$ $1.8 \mathrm{Kcal} / \mathrm{mol}$. These $E_{\mathrm{a}}$ values are considerably lower than those reported for FA decomposition by means of a non-catalyzed process. ${ }^{[21]}$ Taking into consideration the limitations inherent to DFT calculations for the quantitative prediction of activation energies for these types of systems, the theoretical activation energy $(17.8 \mathrm{Kcal} / \mathrm{mol})$ agrees well with the experimental energy barrier calculated by the Arrhenius plots (SI). By DFT calculations, we were unable to model an alternative mechanism triggered by the presence of water that would lead to a lower energy pathway. In particular, the use of a water molecule as proton shuttle does not reduce the activation energy of the rate-limiting step, the $\beta$ hydride elimination (TSCF).

In conclusion, we have demonstrated that $\mathbf{1}$ is an exceptionally active catalyst for the dehydrogenation of neat FA. The fact that $\mathbf{1}$ performs markedly better than complexes $\mathbf{3}$ and $\mathbf{4}$ emphasizes the importance of the NHO moiety, which is key to the success of the reaction. The DFT calculations presented here agree with the stoichiometric reactions that lead to compounds 5 and $\mathbf{6}$, which are closely related to intermediate $\mathbf{G}$. Moreover, the low activity of $\mathbf{2}$ agrees with the postulated mechanism, which requires a vacant coordination site at the position that the carbonyl ligand occupies. Remarkably, the addition of water to the reaction mixture significantly increases the reaction rates. The effect of water seems to be related to solvation effects since no lower energy pathways could be predicted by DFT calculations.

\section{Acknowledgements ((optional))}

This work was supported by the Spanish Ministry of Education, Culture and Sports (MECD) (project CTQ2016-75884-P, "Ramón y Cajal" program (M.I.) and FPU14/06003 (J.M.)) and the DGA/E42_17R. J.M. and V.P. gratefully acknowledge the resources from the supercomputer "memento" and technical assistance provided by BIFI-ZCAM.

\section{Keywords: Dehydrogenation • Iridium • NHO • Formic Acid • Hydrogen Storage}

[1] a) G. W. Huber, S. Iborra, A. Corma, Chem. Rev. 2006, 106, 4044-4098; b) V. Smil, Energy at the Crossroads, Global Perspectives and Un certainties; MIT Press: Cambridge, 2003.

[2] a) D. A. J. Rand, R. M. Dell, Hydrogen Energy-Challenges and Prospects RSC Publishing, Cambridge, 2008; b) Hydrogen as a Future Energy Carrier; (Eds. A. Züttel, A. Borgschulte, L. Schlapbach), Wiley-VCH Verlag $\mathrm{GmbH} \&$ Co. KgaA, Weinheim, 2008

[3] a) F. Joó, ChemSusChem 2008, 1, 805-808; b) N. A. Kelly in In Advances in Hydrogen Production, Storage and Distribution, Chapter 6 (Eds. A. Basile and A. Iulianelli), Woodhead Publishing, Cambridge, 2014; pp 159-185.

[4] a) P. Preuster, C. Papp, P. Wasserscheid, Acc. Chem. Res. 2017, 50 74-85; b) D. Teichmann, W. Arlt, P. Wasserscheid, Int. J. Hydrog. Energy 2012, 37, 18118-18132.

[5] a) J. Eppinger, K.-W. Huang, ACS Energy Lett. 2017, 2, 188-195; b) Ullmann's Encyclopedia of Industrial Chemistry, Vol. A12 (Eds.: B. Elvers, S. Hawkings, M. Ravenscroft, F. Rounsaville, G. Schulz), Wiley- $\mathrm{VCH}$, Weinheim, 1989, pp. 13-33.

[6] B. Loges, A. Boddien, H. Junge, M. Beller, Angew. Chem. Int. Ed. 2008, 47, 3962-3965.

[7] C. Fellay, P. J. Dyson, G. Laurenczy, Angew. Chem. Int. Ed. 2008, 47, 3966-3968.

[8] K. Sordakis, C. Tang, L. K. Vogt, H. Junge, P. J. Dyson, M. Beller, G. Laurenczy, Chem. Rev. 2018, 118, 372-433.

[9] a) S. Oldenhof, B. de Bruin, M. Lutz, M. A. Siegler, F. W. Patureau, J. I. van der Vlugt, J. N. H. Reek, Chem. Eur. J. 2013, 19, 11507-11511; b) S. Cohen, V. Borin, I. Schapiro, S. Musa, S. De-Botton, N. V. Belkova, D. Gelman, ACS Catal. 2017, 7, 8139-8146.

[10] J. J. A. Celaje, Z. Lu, E. A. Kedzie, N. J. Terrile, J. N. Lo, T. J. Williams, Nat. Commun. 2016, 7, 11308. 
[11] a) M. Iglesias, A. Iturmendi, P. J. Sanz Miguel, V. Polo, J.J. PérezTorrente, L. A. Oro, Chem. Commun. 2015, 51, 12431; b) A. Iturmendi, N. García, E. A. Jaseer, J. Munárriz, P. J. Sanz Miguel, V. Polo, M. Iglesias, L. A. Oro, Dalton Trans. 2016, 45, 12835-12845.

[12] Complexes 3 and $\mathbf{4}$ were prepared according to literature procedures: a) M. P. Betore, M. A. Casado, P. García-Orduña, F. J. Lahoz, V. Polo, L. A. Oro, Organometallics 2016, 35, 720-731; b) T. Makino, Y. Yamamoto, K. Itoh, Organometallics 2004, 23, 1730-1737; c) W. A. Fordyce, G. A Crosby, Inorg. Chem. 1982, 21, 1455-1461.

[13] For examples see: a) J. Li, J. Li, D. Zhang, C. Liu, ACS Catal. 2016, 6, 4746-4754; b) C. Fellay, N. Yan, P. J. Dyson, G. Laurenczy, Chem. Eur. J. 2009, 15, 3752-3760; c) L. S. Jongbloed, B. de Bruin, J. N. H. Reek, M. Lutz, J. I. van der Vlugt, Catal. Sci. Technol. 2016, 6, 1320-1327; d) A. Boddien, D. Mellmann, F.Gärtner, R. Jackstell, H. Junge, P. J. Dyson, G. Laurenczy, R. Ludwig, M. Beller, Science 2011, 333, 1733-1736.

[14] M. Iglesias, L. A. Oro, Eur. J. Inorg. Chem. 2018, 2125-2138.

[15] S. Fukuzumi, T. Kobayashi, T. Suenobu, J. Am. Chem. Soc. 2010, 132, 1496-1497.

[16] a) F. J. Fernández-Alvarez, M. Iglesias, L. A. Oro, V. Polo; ChemCatChem 2013, 5, 3481-3494; b) X. Yang, Dalton Trans., 2013 42, 11987-11991; c) T. Zell, B. Butschke, Y. Ben-David, D. Milstein Chem. Eur. J. 2013, 19, 8068-8072; d) E. A. Bielinski, P. O. Lagaditis, Y. Zhang, B. Q. Mercado, C. Würtele, W. H. Bernskoetter, N. Hazari, S. Schneider, J. Am. Chem. Soc. 2014, 136, 10234-10237.
[17] For examples see: a) A. Matsunami, Y. Kayaki, T. Ikariya Chem. Eur. J. 2015, 21, 13513-13517; b) T. Abura, S. Ogo, Y. Watanabe, S. Fukuzumi, J. Am. Chem. Soc. 2003, 125, 4149-4154; c) T. Zell, B. Butschke, Y. Ben-David, D. Milstein, Chem. Eur. J. 2013, 19, 8068-8072; d) A. Boddien, B. Loges, F. Gärtner, C. Torborg, K. Fumino, H. Junge, R Ludwig, M. Beller, J. Am. Chem. Soc. 2010, 132, 8924-8934.

[18] a) P. J. Dyson, P. G. Jessop, Catal. Sci. Technol. 2016, 6, 3302-3316; b) K. Leung, S. B. Rempe, J. Am. Chem. Soc. 2004, 126, 344-351; c) N Akiya, P. E. Savage, AlChE J. 1998, 44, 405-415.

[19] a) S. Siek, D. B. Burks, D. L. Gerlach, G. Liang, J. M. Tesh, C. R Thompson, F. Qu, J. E. Shankwitz, R. M. Vasquez, N. Chambers, G. J Szulczewski, D. B. Grotjahn, C. E. Webster, E. T. Papish Organometallics 2017, 36, 1091-1106; b) J. F. Hull, Y. Himeda, W.-H. Wang, B. Hashiguchi, R. Periana, D. J. Szalda, J. T. Muckerman, E. Fujita, Nat. Chem. 2012, 4, 383-388; c) S. Fukuzumi, T. Kobayashi, T. Suenobu, ChemSusChem 2008, 1, 827-834.

[20] a) A. Matsunami, S. Kuwata, Y. Kayaki, ACS Catal. 2017, 7, 4479-4484; b) A. Matsunami, Y. Kayaki, T. Ikariya Chem. Eur. J. 2015, 21, 1351313517.

[21] P. Ruelle, U. W. Kesselring, H. Nam-Tran, J. Am. Chem. Soc. 1986, 108 371-375 
Layout 1:

\section{COMMUNICATION}

NHOs make a difference: An NHO donor moiety embedded into a PCP ligand triggers outstanding activities in the solventless dehydrogenation of formic acid catalyzed by a robust PCP-iridium catalyst. Addition of water to the reaction enhances the catalytic activity, leading to a TOF value of $11590 \mathrm{~h}^{-1}$ and a TON of 8030 after 5 h.

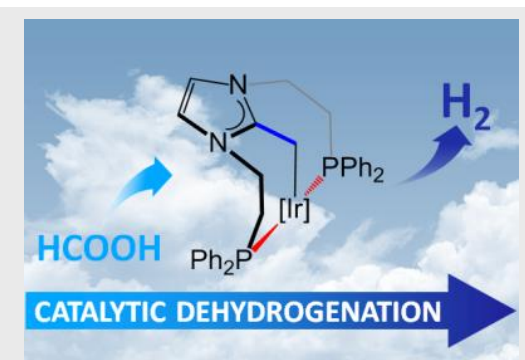

Amaia Iturmendi, Manuel Iglesias*, Julen Munarriz, Victor Polo, Vincenzo Passarelli, Jesús J. Pérez-Torrente, Luis A. Oro*

Page No. - Page No.

Highly Efficient Ir-Catalyst for the Solventless Dehydrogenation of Formic Acid: The Key Role of an $\mathrm{N}$ heterocyclic Olefin 